\title{
Utilization of Volatile Fatty Acids from Microalgae for the Production of High Added Value Compounds
}

\author{
Angelina Chalima ${ }^{1}$, Laura Oliver ${ }^{2}$, Laura Fernández de Castro ${ }^{2}$, Anthi Karnaouri ${ }^{1}$, \\ Thomas Dietrich ${ }^{2}$ and Evangelos Topakas $1,3, *$ \\ 1 IndBioCat group, Biotechnology Laboratory, School of Chemical Engineering, National Technical University \\ of Athens, 5 Iroon Polytechniou Str., Zografou Campus,15780 Athens, Greece; \\ achalima@chemeng.ntua.gr (A.C.); akarnaouri@chemeng.ntua.gr (A.K.) \\ 2 Food \& Health Group, Health Division, Tecnalia Research \& Innovation, Parque Tecnológico de Álava, \\ Leonardo Da Vinci, 11, E-01510 Miñano-Álava, Spain; laura.oliver@tecnalia.com (L.O.); \\ laura.fernandezdecastro@tecnalia.com (L.F.d.C.); thomas.dietrich@tecnalia.com (T.D.) \\ 3 Biochemical and Chemical Process Engineering, Division of Sustainable Process Engineering, \\ Department of Civil Environmental and Natural Resources Engineering, Luleå University of Technology, \\ SE-97187 Luleå, Sweden \\ * Correspondence: vtopakas@chemeng.ntua.gr; Tel.: +30-210-772-3264
}

Received: 9 September 2017; Accepted: 9 October 2017; Published: 15 October 2017

\begin{abstract}
Volatile Fatty Acids (VFA) are small organic compounds that have attracted much attention lately, due to their use as a carbon source for microorganisms involved in the production of bioactive compounds, biodegradable materials and energy. Low cost production of VFA from different types of waste streams can occur via dark fermentation, offering a promising approach for the production of biofuels and biochemicals with simultaneous reduction of waste volume. VFA can be subsequently utilized in fermentation processes and efficiently transformed into bioactive compounds that can be used in the food and nutraceutical industry for the development of functional foods with scientifically sustained claims. Microalgae are oleaginous microorganisms that are able to grow in heterotrophic cultures supported by VFA as a carbon source and accumulate high amounts of valuable products, such as omega-3 fatty acids and exopolysaccharides. This article reviews the different types of waste streams in concert with their potential to produce VFA, the possible factors that affect the VFA production process and the utilization of the resulting VFA in microalgae fermentation processes. The biology of VFA utilization, the potential products and the downstream processes are discussed in detail.
\end{abstract}

Keywords: volatile fatty acids; waste valorization; microalgae; bioactive compounds; omega-3 fatty acids

\section{Introduction}

The term Volatile Fatty Acids (VFA) is applied to short-chain fatty acids, usually consisted of two to six carbon atoms, such as acetic, butyric or propionic acid [1]. VFA are organic chemicals with various applications; they can be provided as carbon sources to microorganisms that produce useful metabolites or remove organic pollutants from waste water, they are utilized for electricity or hydrogen generation and they can serve as starting materials for the synthesis of long-chain fatty acids and polyhydroxyalkanoates (PHAs) for packaging applications [2].

VFA can be easily produced by all types of biomass (terrestrial, marine and aquatic) and within the frame of VFA platform, they can be used for the production of biofuels and biochemicals, offering a solution for efficient waste management. Valorization of VFA can be achieved via their efficient 
transformation into value-added products. Bioactive compounds such as omega-3 fatty acids can be obtained through fermentation processes that use VFA as carbon source for microorganisms.

According to recent research, some microalgae, able to grow heterotrophically, are capable of utilizing dissolved carboxylic acids such as VFA as carbon source [3]. Microalgae use short-chain fatty acids to produce metabolites, such as long chain unsaturated fatty acids (e.g., omega-3 fatty acids or arachidonic acid) or carotenoids. In this case, the first step of breaking down the carbon sources to simple sugars is eliminated, since VFA provide microalgae with a carbon chain backbone ready to be elongated to polyunsaturated fatty acids (PUFAs) [4].

This ability of certain microalgal species is opening a new perspective in the industrial production of high added-value products, while using as raw material undesirable persistent pollutants. The main metabolites of microalgae are lipids able to be esterified to produce biodiesel, long-chain polyunsaturated fatty acids and pigments. Several pigments and PUFAs, such as omega- 3 fatty acids, are valuable products, with great importance for the food and pharmaceutical market. Therefore, the development of appropriate fermentation techniques that utilize VFA not only poses a solution to the elimination of these pollutants, but also offers an affordable production process of useful metabolites.

Due to the rising awareness among consumers about healthy and balanced diet, the market for omega-3 fatty acids especially eicosapentaenoic acid (EPA) and docosahexaenoic acid (DHA) is supposed to grow at a Compound Annual Growth Rate (CAGR) of 14.9\% from 2016 to 2022 reaching a value of $\$ 6955$ million by 2022 [5]. In general, fish oil or fish is a good source for DHA and EPA. Nevertheless, as the demand for omega- 3 fatty acids is continuously rising and more and more fish is coming from aquaculture, it comes inevitably that traditional finite marine ingredients (e.g., fish oil) are replaced by terrestrial oils leading to a reduction of EPA and DHA and thereby compromising the nutritional value of the final fish product. Between 2006 and 2015, the amount of EPA and DHA requiring a double portion size in order to satisfy recommended levels [6]. Therefore, new sources (e.g., heterotrophic microalgae) and innovative production processes not relying on agricultural area and food grade carbon sources are needed to supply this gap.

\section{Production of VFA from Waste Streams}

\subsection{VFA Production through Dark Fermentation}

The synthesis of VFA is usually carried out through petrochemical processes that have a hazardous environmental impact [7]. On the other hand, VFA can be produced from food wastes, sludge, and a variety of biodegradable organic wastes via dark fermentation process, making the process more efficient and profitable from economic and environmental point of view. Dark fermentation initially follows the same pattern as the classical anaerobic digestion (hydrolysis, acidogenesis, acetogenesis) with the difference that the final step of methanogenesis is inhibited by various methods [8]. Hydrolysis, the first and usually the slowest step part of anaerobic digestion, includes the enzymatic breakdown of long polymeric substances to simpler organic monomers such as sugars, amino acids and fatty acids. These monomers are subsequently fermented by acidogenic populations in the acidogenesis step, leading to production of VFA (mainly acetate), together with an air mixture of hydrogen and carbon dioxide. Acetogenesis represents the stage where the breakdown of VFA to hydrogen and acetate occurs [9]. In order to utilize dark fermentation to produce VFA, the consumption of fatty acids by methanogens must be prevented. Therefore, in the above process, the last step of methanogenesis is inhibited, usually either by thermal pretreatment of the waste stream to destroy the methanogenic populations, or by maintaining the $\mathrm{pH}$ of the mixture at high values (above 9) that do not allow the growth of the specific bacteria $[10,11]$. Another solution is the addition of a methanogen inhibitor, such as iodoform [12,13]. Due to methanogenesis inhibition, dark fermentation usually leads to hydrogen and VFA accumulation, especially high carbon fatty acids such as caproate, production of ethanol and accumulation of lactate $[14,15]$. 
As already mentioned, the slowest and, therefore, rate-limiting step of dark fermentation is the hydrolysis of solids in the waste stream [11]. This is related to the overall recalcitrance of the biomass structure due to different factors that render the substrate unavailable to hydrolysis, as well as the presence of compounds, such as phenolics and the low $\mathrm{C} / \mathrm{N}$ ratio together with high levels of trace elements that inhibit the degradation [16,17]. In order to increase VFA production, the hydrolysis rate and/or efficiency should be enhanced. The biodegradability of the waste materials can be improved by the application of an initial pretreatment step that will convert raw materials to a form amenable to enzymatic and microbial degradation. As a result, the vast majority of dark fermentation applications usually involve the use of a suitable pretreatment process of the waste stream prior to biological treatment. Hydrolysis can be enhanced either by thermal, ultrasonic, microwave or chemical pretreatment with acid, alkali, surfactants, ozone or other reactive substances [18-20]. These methods damage cell walls, releasing intracellular substances and/or enhance the solubilization of extracellular matter. An alternative way to boost the hydrolysis step is to apply an enzymatic treatment with commercial enzyme mixtures, where specific activities targeting particular waste components can be used, while different parameters like enzyme dosage and hydrolysis time can be controlled towards maximum monomers yields [21]. Hee Jun Kim et al., for example, used a mixture of the commercial enzymes Viscozyme, Flavourzyme and Palatase (carbohydrase, protease, lipase) to pretreat raw food waste in order to maximize VFA production during dark fermentation. The new production rate of VFA was 3.3 times higher after the enzymatic treatment [22]. Another commercial enzyme cocktail that has been applied to enhance the solubilization of pulp and paper mill secondary sludge is Accellerase 1500, known for its applications on cellulose hydrolysis [23]. To the best of our knowledge a certain enzyme available for every type of waste stream has not yet been identified. However, Q. Yang et al. have concluded that a treatment of sludge with amylases is more efficient than one with proteases [24]. Since an enzymatic treatment can increase the cost of the whole process, it is suggested not to rely solely on enzymes to enhance waste hydrolysis. Usually a combination of the previously listed techniques is preferable.

An established method that includes the production of VFA through dark fermentation is the MixAlco ${ }^{\mathrm{TM}}$ process. The MixAlco ${ }^{\mathrm{TM}}$ process is used to convert biomass into carboxylate salts through dark fermentation by a mixed-culture of microorganisms. In a second step of the process the salts are converted to ketones and fuels. The interesting part of this technique is that it utilizes countercurrent fermentation through a number of fermenters, thus allowing the feed with the lowest VFA concentration to mix with the most fermented biomass and vice versa [25]. The advantage of this is based on the fact that the products of the fermentation process, namely VFA, can act as inhibitors to the growth of acidogens, resulting in slow production rates [26].

\subsection{Available Waste Streams for VFA Production and VFA Yields}

All types of biomass can be used as substrates for biogas production as long as they contain carbohydrates, proteins, fats, cellulose, and hemicelluloses as main components. Waste streams that are deemed appropriate for VFA production should have a high organic load that can support the growth of acidogenic bacteria. Amongst the most popular waste streams for dark fermentation are various types of sludge, wastewaters from paper or agricultural industries and food waste (Table 1). Some of the streams that are being used, like waste activated sludge, already include the appropriate bacteria population, whilst others have to be inoculated with an external bacterial consortium.

In many applications, the streams that are destined for VFA production are a mixture of different waste streams e.g., agricultural waste and animal manure [13] or waste activated sludge (WAS) and corn stover [27]. The purpose behind mixing different waste streams is the development of a substrate with a balanced carbohydrate: protein ratio, which in turn answers for a balanced $\mathrm{C} / \mathrm{N}$ ratio. According to various experiments $[27,28]$ it has been found that a higher $C / N$ ratio (around 20/1-30/1) can be beneficial to the microorganisms responsible for acidogenesis. Furthermore, it is believed that the carbohydrate amount can have a synergistic effect with WAS. Therefore, the addition of a rich 
in carbohydrate-waste stream to the original substrate can lead to enhanced VFA productivity [29]. However, it does not follow that a rich in protein-waste stream would not be able to produce VFA through dark fermentation. Pessiot et al. have managed to produce a considerable amount of VFA from slaughterhouse waste [30]. Due to the high amount of nitrogen available in the specific waste stream, the production of $\mathrm{N}_{2}$ emissions and nitrogen ions, that buffered successfully the mixture, was also observed, together with VFA production. As it is, the use of waste rich in nitrogen seems to offer a different advantage, which is the ability to maintain a high $\mathrm{pH}$ value during the fermentation, without the need of a buffer feed.

The liquid product stream of dark fermentation processes consists of a mixture of VFA with different compositions. In the vast majority, the dominant acid in these mixtures is acetic acid, followed by propionic acid (Table 1). Acetic acid seems to have a higher value as a product, since it is more easily consumed by several microorganisms [31]. However, since it is classified as a hazardous pollutant for the environment, its production through dark fermentation needs to be justified by its utilization as a raw material for the production of high added-value products. The composition of the acid fraction of the liquid product depends on various variables, like the type of waste stream used and the fermentation conditions ( $\mathrm{pH}$, fermentation time, etc.) $[1,28]$. The $\mathrm{pH}$ value for example plays an important role in the synthesis of different VFA. It has been reported in the literature that, during the fermentation of a synthetic gelatin wastewater, $\mathrm{pH}$ values between 4.0-5.0 favors the production of propionic acid, while a $\mathrm{pH}$ around 6.0-7.0 favors the production of acetic and butyric acid, instead [32]. Chen et al. also noticed that, during the fermentation of a mixture of primary and waste activated sludge, the proportion of acetate increased when the $\mathrm{pH}$ increased from 7.9 to 8.9 [33].

Regarding the composition of waste, it has been proposed that a higher $\mathrm{C} / \mathrm{N}$ ratio, under the appropriate $\mathrm{pH}$ conditions, favors the production of propionate. Propionic acid is supposed to enhance the efficiency of biological phosphorus removal from wastewater, when VFA are used as a carbon source for nutrient removal [28]. For that reason, Feng et al. mixed WAS with boiled rice in order to produce a rich in carbohydrates substrate suitable for VFA production.

\subsection{VFA Platform for Fuels and Chemicals}

The development of a platform that enables the production of a mixture of VFA from bio-waste by dark fermentation, thus consuming the organic load of this waste, can offer instant environmental relief. When compared to other biorefinery platforms, such as syngas (thermochemical), sugar and biogas, the VFA platform offers unique advantages [34]. This platform enables the use of all types of biomass and waste streams, leading to high productivity levels (high VFA yields) with low production costs, while enabling possible hydrogen co-production. Moreover, it has lower $\mathrm{CO}_{2}$ emission than a typical sugar platform.

In order to ensure that VFA utilization processes will not release to the environment pollutants such as acetic acid, it is necessary to convert VFA to high added-value substances in a sustainable manner. Fermentation techniques have gained immense importance due to their economic and environmental advantages. Establishing a VFA platform and incorporating fermentative production routes towards value-added compounds, comprise a key step for the implementation of sustainable value chains for the use of biomass wastes. In this context, the European funded research project VOLATILE (Grant Agreement No. 720777) offers a great opportunity to transform municipal solid and sludgy biowaste into VFA to be used as carbon sources for value-added fermentation approaches to obtain omega-3 fatty acids, the biopolymer PHA as well as single cell oil. 
Table 1. Different waste streams used for Volatile Fatty Acids (VFA) production.

\begin{tabular}{|c|c|c|c|c|c|}
\hline Waste Stream & Process & $\begin{array}{l}\text { Fermentation Key } \\
\text { Conditions }{ }^{1}\end{array}$ & VFA Yield ${ }^{2}$ & $\begin{array}{l}\text { VFA Composition } \\
\text { (mol) }\end{array}$ & Ref. \\
\hline $\begin{array}{l}\text { Pulp and paper } \\
\text { mill effluent }\end{array}$ & Continuous & $\mathrm{pH}=6, \mathrm{RT}=24 \mathrm{~h}, \mathrm{~T}=37^{\circ} \mathrm{C}$ & $0.75 \mathrm{~g}$ COD $/ \mathrm{g}$ COD & 33Ac:61Pr:2Bu & [35] \\
\hline Dairy whey effluent & Continuous & $\mathrm{pH}=6, \mathrm{RT}=95 \mathrm{~h}, \mathrm{~T}=37^{\circ} \mathrm{C}$ & $0.93 \mathrm{~g} \mathrm{COD} / \mathrm{g}$ COD & 31Ac:41Pr:10Bu & [35] \\
\hline Swine manure & $\begin{array}{c}\text { Batch (2d)/ } \\
\text { Semi-continuous (10d) }\end{array}$ & $\begin{array}{c}\mathrm{T}=38 \pm 1^{\circ} \mathrm{C}, \mathrm{pH}=5.3-5.6 \\
\mathrm{HRT}=3 \mathrm{~d}\end{array}$ & $2002.25 \mathrm{mg} \mathrm{L}^{-1} \mathrm{~d}^{-1}$ & & [10] \\
\hline $\begin{array}{l}\text { Waste Activated } \\
\text { Sludge (WAS) }\end{array}$ & Batch & $\mathrm{T}=35 \pm 1^{\circ} \mathrm{C}, \mathrm{pH}=10$ & $129.21 \mathrm{mg} / \mathrm{g}$ VS & & [36] \\
\hline $\begin{array}{l}\text { Mixture of primary sludge } \\
\text { (PS)/ WAS }(w / w: 1: 1)\end{array}$ & Semi-continuous & $\mathrm{T}=21 \pm 1^{\circ} \mathrm{C}, \mathrm{SRT}=6 \mathrm{~d}$ & $\begin{array}{c}118.4 \pm 5.8 \mathrm{mg} \\
\text { COD/g VSS }\end{array}$ & 10Ac:7Pr:4Bu:5Va & [33] \\
\hline Excess Sludge (ES) & Batch & $\mathrm{T}=28^{\circ} \mathrm{C}, \mathrm{pH}=10$ & $\begin{array}{l}302.4 \mathrm{mg} \mathrm{COD} / \mathrm{g} \\
\text { VSS }\end{array}$ & $\begin{array}{l}\text { 53Ac:24Pr:9Bu: } \\
\text { 9Iso-bu:9Iso-va }\end{array}$ & [37] \\
\hline $\begin{array}{l}80 \% \text { lime-treated } \\
\text { sugarcane bagasse } / 20 \% \\
\text { chicken manure }\end{array}$ & Continuous & $\begin{array}{c}\mathrm{T}=55^{\circ} \mathrm{C}, \mathrm{pH}=6.95-7.05 \\
\mathrm{LRT}=19.1 \mathrm{~d} \\
\text { VSLR }=2.07 \mathrm{~g} /(\mathrm{L} \cdot \text { day })\end{array}$ & $\begin{array}{l}0.55 \mathrm{~g} \mathrm{TA} / \mathrm{g} \text { VS } \\
\text { digested }\end{array}$ & 91Ac:2Pr:7Bu:0.6Va & [13] \\
\hline $\begin{array}{l}\text { Slaughterhouse } \\
\text { by-products }\end{array}$ & Fed-batch & $\mathrm{T}=38^{\circ} \mathrm{C}, \mathrm{pH}_{\text {initial }}=6.8$ & $\begin{array}{l}0.38 \pm 0.04 \mathrm{~g} \text { VFA } / \mathrm{g} \\
\text { DM consumed }\end{array}$ & $\begin{array}{l}\text { 63Ac:43Pr:59Bu: } \\
\text { 13Iso-Bu:24Va }\end{array}$ & [30] \\
\hline $\begin{array}{c}80 \% \text { shredded office copier } \\
\text { paper } / 20 \% \\
\text { chicken manure }\end{array}$ & Semi-continuous & $\begin{array}{c}\mathrm{T}=40^{\circ} \mathrm{C}, \mathrm{pH}=5.3-6.6 \\
\mathrm{LRT}=32.6 \mathrm{~d}\end{array}$ & $\begin{array}{l}0.159 \mathrm{~g} \text { acid } / \mathrm{g} \\
\text { NAVS fed }\end{array}$ & $\begin{array}{l}\text { 36Ac:37Pr:7Bu: } \\
\text { 14Va:6Hep }\end{array}$ & [25] \\
\hline WAS/ rice & Batch & $\begin{array}{l}\mathrm{T}=21 \pm 1{ }^{\circ} \mathrm{C}, \mathrm{pH}=8 \\
\text { fer. Time }=8 \mathrm{~d}\end{array}$ & $\begin{array}{l}520.1 \pm 24.4 \mathrm{mg} \\
\text { COD/g VSS }\end{array}$ & 35Ac:50Pr & [28] \\
\hline $\begin{array}{l}\text { Alkaline, thermal } \\
\text { pretreated WAS/ ABS }\end{array}$ & Batch/Semi-continuous & $\mathrm{T}=35 \pm 2{ }^{\circ} \mathrm{C}, \mathrm{HRT}=10 \mathrm{~d}$ & $\begin{array}{l}712 \pm 49 \mathrm{mg} \\
\text { COD/g VSS }\end{array}$ & $46 \pm 0.9 \% \mathrm{Ac}$ & [18] \\
\hline $\begin{array}{c}\text { Pretreated WAS/ } \\
\text { pretreated corn stover } \\
(50: 50)\end{array}$ & Batch & $\mathrm{T}=35 \pm 1^{\circ} \mathrm{C}, \mathrm{pH}_{\text {initial }}=10$ & $11939 \mathrm{mg}$ COD/L & 52Ac:22Pr:10n-Bu:8iso-Va & [27] \\
\hline $\begin{array}{l}\text { WAS pretreated with } \\
\text { rhamnolipids } \\
(0.04 \mathrm{~g} / \mathrm{g} \text { TSS })\end{array}$ & Batch & $\mathrm{T}=35 \pm 1{ }^{\circ} \mathrm{C}$, fer. time $=4 \mathrm{~d}$ & $3840 \mathrm{mg}$ COD/L & $\begin{array}{c}\text { Ac }(25 \pm 0.6 \%): \operatorname{Pr} \\
(20 \pm 0.1 \%): \mathrm{n}-\mathrm{HBu} \\
(16 \pm 0.1 \%)\end{array}$ & [20] \\
\hline
\end{tabular}

\section{Microalgae Potential in VFA Valorization}

Microalgae are microorganisms that can grow both phototrophically and heterotrophically. When under dark, some microalgae strains can consume a carbon source and grow, while producing useful metabolites, such us lipids (e.g., omega-3 fatty acids) and pigments [3]. It has also been found that certain microalgae species would grow on different carbon sources, such as glucose, glycerol, ethanol and volatile organic acids. Apart from pure organic acids, VFA derived from dark fermentation processes have also been used as a carbon source for the cultivation of certain microalgae strains, like Chlorella vulgaris and Auxenochlorella protothecoides [3,38]. Therefore, microalgae appear as a mean of bioconversion of VFA from fermented biowaste to high added-value products.

\subsection{Biology of VFA Utilization;}

Microalgae are ubiquitous organisms that are extremely diverse and heterogeneous from evolutionary and ecological point of view. They constitute prokaryotic cyanobacteria and eukaryotic protists and therefore exhibit variation in their nutritional requirements, as well as metabolite production. Commonly, microalgae are considered photoautotrophic organisms; however, several species use heterotrophic metabolism [39]. The interest in heterotrophic microalgae production is driven by the fact that it addresses many of the problems that have hampered the successful widespread implementation of photosynthetic microalgae cultivation systems [40].

Heterotrophic growth using carboxylic acids, such as acetic, citric, fumaric, glycolic, lactic, malic, pyruvic and succinic, as a substrate has been demonstrated for microalgae species [41]. Acetic acid is an intermediate of anaerobic digestion. It often accumulates in dark fermentation processes and can be easily converted by microalgae into acetyl-CoA, the main precursor for lipid synthesis [42]. Eukaryotic microorganisms are able to assimilate acetate via a monocarboxylic/proton transporter protein that 
aids transport of monocarboxylic molecules across the membrane [3] (Figure 1). The transferred acetate is used from the acetyl-CoA synthetase to acetylate coenzyme A using a single ATP molecule [39].

The metabolic oxidation of acetyl-CoA is using two pathways. In the glyoxysomes, the glyoxylate cycle transforms the acetyl-CoA into malate. The second pathway is converting acetyl-CoA into citrate using the tricarboxylic acid (TCA) cycle in the mitochondria, thereby providing carbon skeletons, energy as ATP, and energy for reduction as NADH $[4,43]$. The glyoxylate cycle is a pathway that allows the synthesis of four carbon metabolites from acetyl-CoA and it is similar to the Krebs cycle [43]. Isocitrate lyase and malate synthetase are the two specific enzymes of the glyoxylate cycle. Both enzymes are induced when cells are transferred to media containing acetate [3]. However, for many microorganisms, acetate could be toxic at high concentrations. Therefore, acetate concentration at low level should be used in fed-batch cultures or under $\mathrm{pH}$-auxostat cultivation conditions keeping $\mathrm{pH}$ value constant [3].

In order to induce fatty acid synthesis nitrogen starvation may be used. It could be shown that in this case the glyoxylate pathway, as well as activity of acetyl-CoA synthetase was down regulated $[44,45]$. Thus, Chlamydomonas reinhardtii is using a second pathway via acetate kinase and phosphate acetyltransferase for acetate assimilation, thereby maintaining basic cellular functions and providing energy [45]. Excess carbon can be directly used for fatty acid biosynthesis [44]. Another important aspect during N-deprivation is the reduced activity of isocitrate dehydrogenase resulting in an increase of citrate levels. Citrate can be converted into oxaloacetate and acetyl-CoA via ATP citrate lyase providing further acetyl-CoA for fatty acid biosynthesis [45].

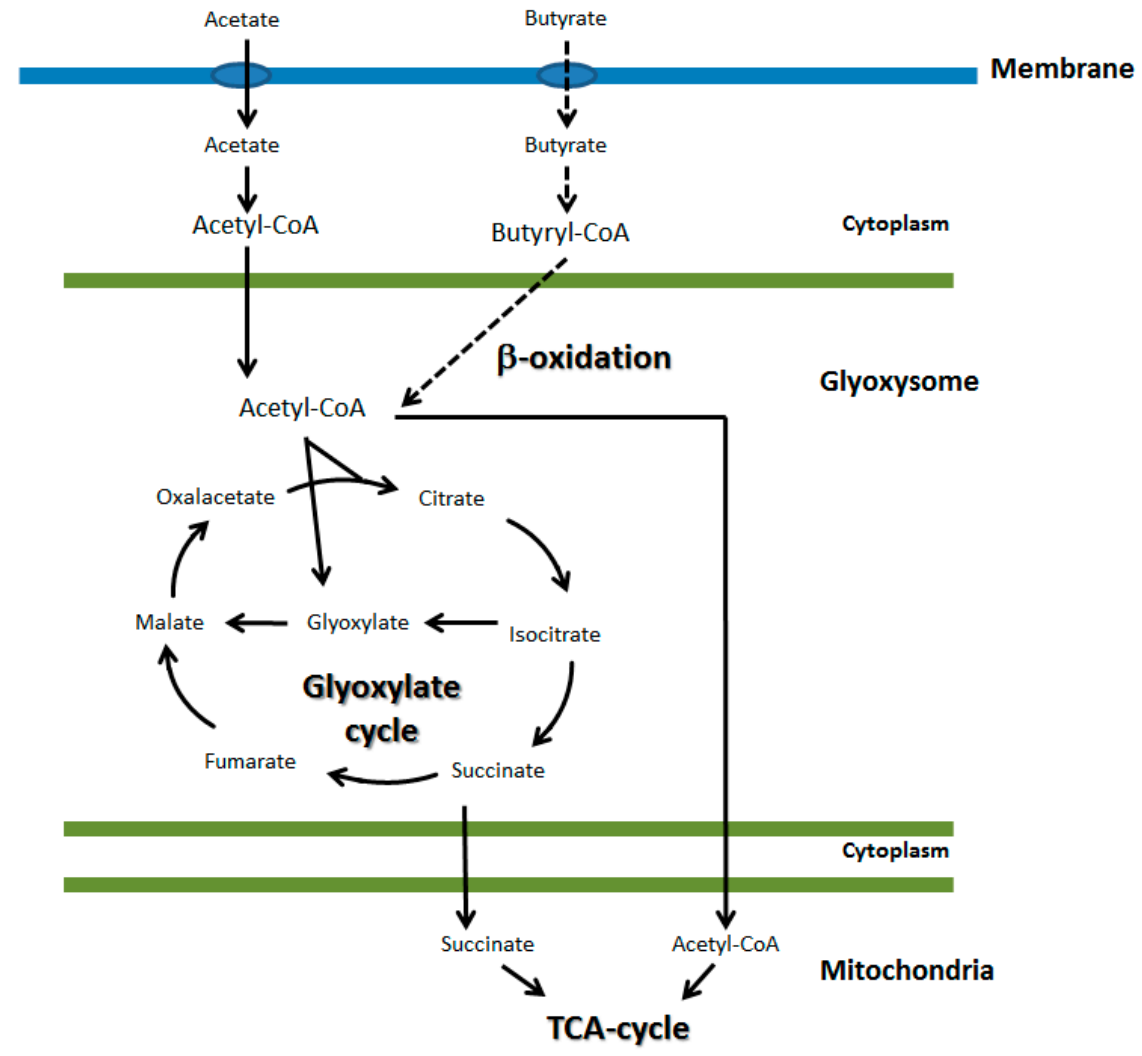

Figure 1. Scheme of metabolic pathways for assimilation of acetate and butyrate.

Butyrate is another major by-product of dark fermentation, but butyrate assimilation by microalgae has not yet been studied in such detail. Butyrate has relatively higher molecular weight and associated complicity and requires more steps for conversion to acetyl-CoA. Similar to transport of acetate, it can be anticipated that butyrate enters via a monocarboxylic/proton transporter across the membrane. In the glyoxysome, butyrate is converted to acetyl-CoA through $\beta$-oxidation [43]. 
The acetyl-CoA is partially used via the glyoxylate cycle for biosynthesis, as well as via the TCA cycle for energy production (Figure 1). For both metabolic cycles, acetyl-CoA is a prerequisite and is mainly provided by $\beta$-oxidation [46]. Although acetate can be efficiently converted into lipids, butyrate uptake by microalgae is much slower and can reduce the microalgae growth when both VFA are present. This problem can be solved either by increasing the initial microalgae biomass or by increasing the initial acetate: butyrate ratio [31].

\subsection{Diverse VFA as a Carbon Source}

Until now, only a limited number of microalgae have been reported in literature to utilize VFA for their growth (Table 2). Various carbon sources have been reported including one only type or mixtures of VFA that include acetate, propionate and butyrate with acetate to be the most commonly used. The process followed for VFA utilization is mainly heterotrophic or mixotrophic, while in one only study, photoheterotrophic fermentation of $C$. vulgaris was carried out [38]. In most cases, VFA were utilized for lipid production with Crypthecodinium cohnii to be the most important player in omega-3 production, while in rare cases VFA was utilized for the production of microalga biomass. Although some microalgae are capable of producing carotenoids, according to literature so far VFA utilization has been linked only with lipid or biomass and no carotenoid production. An exemption to this trend is the production of astaxanthin by Haematococcus pluvialis that has the potential to utilize acetate in a heterotrophic manner [47]. However, the maximum astaxanthin content of H. pluvialis cells was reported to be lower than 3-fold compared to the production carried out by photoautotrophic process. 
Table 2. Microalgal strains that utilize VFA as carbon source.

\begin{tabular}{|c|c|c|c|c|c|}
\hline Strain & Carbon Source & Process & Product & Production & Ref. \\
\hline Chlamydomonas reinhardtii wild-type strain CC-124 & Acetate & mixotrophic & Microalgal oil & $16.41 \pm 1.12 \%$ lipid content & [48] \\
\hline Chlamydomonas reinhardtii wild-type strain CC-124 & $\begin{array}{l}\text { acetic acid: propionic acid: } \\
\text { butyric acid in a ratio } 8: 1: 1\end{array}$ & mixotrophic & Microalgal oil & $19.02 \%$ lipid content & [48] \\
\hline Chlorella protothecoides 249 & Acetate & mixotrophic, initial $\mathrm{pH}=6.5$ & Microalgal oil * & $29.45 \pm 0.84 \%$ lipid content & [49] \\
\hline Chlorella protothecoides 249 & Acetate & heterotrophic, initial $\mathrm{pH}=6.3$ & Microalgal oil & $52.38 \pm 25.77 \%$ lipid content & [49] \\
\hline Chlorella protothecoides FACHB-3 & $\begin{array}{l}\text { WAS hydrolysate containing } \\
\text { a mixture of VFA }\end{array}$ & heterotrophic & Microalgal oil & $21.5 \pm 1.44 \%$ lipid content & [50] \\
\hline Chlorella protothecoides UTEX 25 & $\begin{array}{l}\text { acetic acid: propionic acid: } \\
\text { butyric acid in a ratio } 8: 1: 1\end{array}$ & Heterotrophic (nitrogen source = Urea) & Microalgal oil & $\begin{array}{c}48.7 \pm 2.2 \% \text { lipid content } \\
\quad(0.317 \pm 0.01 \mathrm{~g} / \mathrm{L})\end{array}$ & [51] \\
\hline Chlorella sorokiniana (CCAP 211/8K) & acetate and butyrate & mixotrophic & Microalga biomass & $1.14 \mathrm{~g} \mathrm{CDW} / \mathrm{L}$ & [52] \\
\hline Chlorella sp. (Arctic) ArM0029B & $\begin{array}{l}\text { acetic, propionic and butyric } \\
\text { acids in ratio 6:1:3 (by mass) }\end{array}$ & $\begin{array}{l}\text { CO2 supplied-mixotrophic followed by } \\
\text { the VFA supply }\end{array}$ & Microalgal oil & $65.7 \pm 3.1 \mathrm{mg} / \mathrm{g} \mathrm{CDW}$ & [53] \\
\hline Chlorella vulgaris ESP6 & $\begin{array}{l}\text { mixture of acetate, lactate, } \\
\text { butyrate, and HCO- }\end{array}$ & photoheterotrophic, constant $\mathrm{pH}=7.5$ & Microalga biomass & $0.87 \mathrm{~g} \mathrm{CDW} / \mathrm{L}$ & [38] \\
\hline Chlorella vulgaris UTEX 259 & Acetate & mixotrophic & Microalgal oil & $36 \pm 1 \%$ lipid content & [54] \\
\hline Crypthecodinium cohnii strain ATCC 30772 & Acetate & heterotrophic (pH-auxostat culture) & DHA & $4.4 \mathrm{~g} / \mathrm{L}$ & [55] \\
\hline Ettlia sp. YC001 & $\begin{array}{l}\text { acetic, propionic and butyric } \\
\text { acids in ratio 6:1:3 (by mass) }\end{array}$ & $\begin{array}{l}\text { CO2 supplied-mixotrophic followed by } \\
\text { the VFA supply }\end{array}$ & Microalgal oil & $88.5 \pm 0.0 \mathrm{mg} / \mathrm{g} C D W$ & [53] \\
\hline Haematococcus pluvialis NIES-144 & Acetate & heterotrophic & astaxanthin & $22.6 \mathrm{mg} / \mathrm{g}$ CDW & [47] \\
\hline Micractinium inermum F014 & $\begin{array}{l}\text { acetic, propionic and butyric } \\
\text { acids in ratio 6:1:3 (by mass) }\end{array}$ & $\begin{array}{l}\text { CO2 supplied-mixotrophic followed by } \\
\text { the VFA supply }\end{array}$ & Microalgal oil & $62.6 \pm 0.5 \mathrm{mg} / \mathrm{g}$ CDW & [53] \\
\hline Scenedesmus obliquus (UTEX 78) & Acetate & mixotrophic & Microalga biomass & $>1.4$ day $^{-1}$ growth rate & [56] \\
\hline Scenedesmus sp. strain R-16 & Acetate & heterotrophic & Microalgal oil & $34.4 \%$ lipid content & [57] \\
\hline Scenedesmus sp. strain R-16 & Butyrate & heterotrophic & Microalgal oil & $24.8 \%$ lipid content & [57] \\
\hline
\end{tabular}

* Total fatty acids. CDW $=$ Cell Dry Weight. 


\subsubsection{Acetate as a Single Carbon Source}

Acetic acid is the most abundant of VFA and the one most easily produced. As already mentioned, some microalgae have exhibited the ability to grow heterotrophically on acetate. Scenedesmus obliquus has been found to increase its growth rate under mixotrophic conditions, with the addition of acetate as carbon source, in comparison to the autotrophic one [56]. Also certain Chlorella species are known to grow on acetate as sole carbon source and produce various metabolites [54,58]. In those species, mixotrophic conditions usually favor the acetate uptake and biomass increase more than the heterotrophic ones [48]. This can be attributed to the ability of light to boost the biomass production of microalgae at the starting point of the culture, thus producing biomass and therefore accelerating the apparent heterotrophic uptake of VFA.

The most characteristic example of heterotrophic growth on acetate is that of the heterotrophic microalga Crypthecodinium cohnii. The alga can grow rapidly on acetate in a $\mathrm{pH}$-auxostat were $\mathrm{pH}$ is controlled by addition of acetic acid [55]. This specific microorganism is industrially cultivated for production of DHA.

\subsubsection{Mixture of VFA as Carbon Source}

Apart from acetate, the sole use of butyrate as carbon source has been proposed for heterotrophic or mixotrophic cultivation of microalgae. However, various experiments have showed that butyrate seems to possess an extremely low ability of being assimilated by microalgae [42]. Furthermore, the addition of butyrate together with acetate in the culture broth has been found to act as an inhibitor and slow down the acetate uptake [52]. Therefore, in order to better understand the behavior of microalgae under heterotrophic conditions, we need to examine their ability to grow, not only on a sole VFA as carbon source, but also on mixtures of different composition [43].

Different microalgal species, when grown on a mixture of VFA, consume acetate preferably to the other acids such us butyric or propionic. Therefore, it is a general rule that a higher acetate proportion in the VFA mixture provides higher lipid accumulation and biomass growth. For example, both Chlamydomonas reinhardtii and Chlorella protothecoides were best cultivated in a mixture of acetic, propionic and butyric acid with a ratio of 8:1:1 [48,51]. Another usual ratio for microalgae cultivation, in which acetate is the most abundant acid, is 6:1:3 [53]. The main reason for this ratio preference appears to be the tendency of microalgae to exhibit a diauxic growth behaviour when the culture medium contains a mixture of carbon sources. Initially, only the substrate that supports the highest growth rate is utilized by the alga, while the consumption of other substrates remains repressed. Only after the preferred substrate is totally consumed the microalga begins metabolizing the other carbon sources [59]. For this reason, a high acetate concentration can ensure that enough cells will initially be produced in order to consume the other "poorer" substrates afterwards.

\subsubsection{Dark Fermentation Effluents as Carbon Source}

VFA are the main by-products of dark fermentation process for the production of hydrogen. Microalgae can consume VFA and produce biomass and useful metabolites, posing therefore a very good solution for the reduction of the acid intermediates. However, the dark fermentation effluents contain many substances, apart from VFA that may act as inhibitors to microalgae growth. The consumption of VFA present in those effluents does not follow necessarily the same rules as the consumption of the previously mentioned VFA mixtures.

The composition of a dark fermentation effluent is hard to be estimated, since it is highly dependent on the composition of the waste and the microbial consortium [8]. So far only a small number of experiments have been made in order to examine the growth of certain microalgal species on such effluents. Cho et al. have managed to cultivate $C$. vulgaris on sewage sludge fermentation effluent mixotrophically. It was concluded that the various substances of the effluent did not act as inhibitors to the growth of the alga [60]. In addition, Wen et al. managed to heterotrophically 
grow C. protothecoides on WAS hydrolysate, that contained high amounts of VFA, supplemented with nutrients [50]. It has also been suggested that microalgae grew well in fed-batch cultivation on raw effluents since the slow addition of the effluent caused the VFA concentration to remain lower than the inhibitory level [10].

\subsubsection{Effect of Culture Conditions in VFA Utilization}

Apart from the VFA ratio and the provision of light, various other culture conditions should be taken into consideration in order for the microalgae to grow. The $\mathrm{pH}$ of the culture broth seems to be an important factor. Although the appropriate $\mathrm{pH}$ of each microalga species differs, it has been repeatedly found that controlling the $\mathrm{pH}$ of the process results in higher biomass and product yields than when allowing it to vary naturally [38,50,61]. Under these conditions it is more difficult for pH-related inhibition, caused by the uptake of VFA to be developed, such as cytosolic $\mathrm{pH}$ acidification [62].

The optimal temperature for microalgae growth can enhance the enzymatic activity of several cell proteins, as well as reduce the energy requirements for thermoregulation. However, sometimes lower temperatures that enhance the production of a certain metabolite, due to stress conditions, are adopted. Higher growth temperatures than the optimal cause problems to the culture, especially in case of a mixotrophic process. The oxidase activity of many enzymes, including the ribulose-1,5-bisphosphate carboxylase/oxygenase (RuBisCO) enzyme, in those temperatures rises. As a result, a higher photorespiration rate occurs and an amount of the energy produced during photosynthesis is being wasted [43].

Another very important factor influencing the lipid and biomass growth is the nitrogen source. It is widely accepted that a high $\mathrm{C} / \mathrm{N}$ ratio can accumulate the production of various metabolites, such as carotenoids and lipids, from microalgae, as a response to stress conditions. Therefore, to optimize the incompatible mechanisms of microalgae growth and lipids accumulation usually a method of nitrogen limitation is adopted. However, the nitrogen source that is used is also a rather determinant factor. More specifically, ammonium seems to be the preferred nitrogen source by most species, since it needs the less energy for its breakdown and uptake [3]. After ammonium, organic substrates like urea and glycine are usually more suitable nitrogen sources than inorganic ones [51,61].

Finally, sometimes, also the culture medium plays a role at the biomass growth [63]. For example, Liu et al. discovered that C. zofingiensis could grow faster mixotrophically on Bold's Basal medium with acetate than on Tris-Acetate-Phosphate (TAP) medium, because it could also utilize the inorganic carbon salts [38].

\subsection{Production of Bioactive Compounds from Heterotrophic Microalgae Cultivation}

Production of microalgae has gained a lot of interest in the past decades. Due to their biodiversity, as well as the possibility to manipulate biochemical composition by changing culture conditions, microalgae can synthesize various bioactive chemicals with potential industrial applications. In this context, heterotrophic microalgae cultivation is very attractive for obtaining high added-value products from cellular storage compounds, such as lipids and starch, while being more flexible compared to autotrophic cultivation. Especially, heterotrophic algae naturally have oil content higher than phototrophic ones with a better nutritional profile in fatty acids.

\subsubsection{Omega-3 Fatty Acids}

According to European Food Safety Authority (EFSA-Q-2004-107), there are two main categories of omega-3 fatty acids (n-3 polyunsaturated fatty acids, PUFAs), which differ in function and requirements; the first refers to $\alpha$-linolenic acid (ALA) produced from vegetable oil, while the other includes long chain n-3 polyunsaturated fatty acids (LC n-3 PUFAs) from marine sources. LC-PUFAs, such as EPA and DHA, have been widely recognized as important bioactive compounds that can be used in the food and nutraceutical industry for the development of functional foods with scientifically proven benefits [64]. There have been reported many studies related to health benefits of DHA and 
EPA. ALA is also nutritionally essential and is required for the synthesis of important fatty acids and eicosanoids. Nevertheless, the conversion of ALA to long chain PUFAs depends on several factors, such as the concentration of omega- 6 fatty acids. Available evidence suggests that LC n-3 PUFA (EPA and DHA) may reduce the risk of cardiovascular disease, possibly mediated by prevention of cardiac arrhythmias [65]. Positive effects on blood lipid level can be found if the diet contains long chain polyunsaturated omega-3 fatty acids. Especially, EPA and DHA are associated with reduced risk of cardiovascular diseases due to their positive effect on plasma triglyceride levels. Other potential mechanisms of LC n-3 PUFA on cardiovascular protection are related to the capability to reduce blood pressure, their anti-inflammatory and antiarrhythmic effects as well as lowering thrombotic tendency. Furthermore, improved vascular endothelial function and insulin sensitivity as well as, increased plaque stability and paraoxonase levels are linked to polyunsaturated omega-3 fatty acids [66].

PUFAs have vital structural and functional roles in higher organisms, including human, and are related to prevention of cardiovascular and inflammatory diseases, cancer and diabetes. Fish oil is considered to be the conventional source of PUFAs; however, the process encounters several limitations concerning the reducing fish populations or the presence of contaminants, like dioxins, polychlorinated biphenyls and heavy metals. On the basis of increasing global fish meal and fish oil costs, it is predicted that dietary fish meal and fish oil inclusion levels within compound aqua feeds will decrease in the long term, resulting in lower levels of healthy omega-3 fatty acids in aquaculture produced fish [67]. Therefore, new sources and production systems, taking into consideration sustainability and economic feasibility for long chain polyunsaturated fatty acids, must be developed for direct human consumption as well as for aquaculture. The main source of omega-3 is still fish oil. Since only plants are able to synthesize essential fatty acids, microalgae could supply the whole food chain with these very important components. In addition to fatty acids, algae contain a massive number of very valuable substances and chemical compounds such as lipids and polysaccharides, sterols, phycobiliproteins or antioxidants such as tocopherol (vitamin E), ascorbic acid (vitamin C), carotenoids and the red pigment astaxanthin.

Microalgae are able to accumulate high amounts of EPA and DHA when growing in heterotrophic cultures, supported by a carbon source [68]. The lipid content in heterotrophically cultivation of C. protothecoides has been reported to reach $55 \mathrm{wt}$. \%, which is 4-times greater than the autotrophically grown cultures under similar conditions [69]. The production of PUFAs is commonly observed during the stationary phase, when the cells have most of their biosynthetic capacities redirected to the production of lipids [70]. At present, industrial production of heterotrophic microalgae is hampered by the high economic and environmental costs of glucose, commonly used as main carbon source. Using different waste streams within the frame of a VFA platform as potential substrates, is a promising strategy for developing a sustainable bio-economy.

Although VFA and especially acetate can successfully support microalgal growth, they do not serve to induce lipid production in the cells. In order to do so, an enviromental stress is required. The usual technique that is adopted is cultivation under nitrogen starvation, that is known to enhance the production of lipids in form of triacylglycerides [71]. This, however, means that the accumulation of lipids antagonizes the biomass production. Only very recently, the discovery of some small molecular activators, that enhance the lipid accumulation, without hampering the biomass growth has been made [72].

\subsubsection{Production of Other High Value Added Compounds}

Several algal strains have been explored under heterotrophic cultivation to develop their capacity in producing not only DHA and EPA, but also interesting and high demanded value-added compounds, such as carotenoids, phycobiliproteins, polysaccharides and others. Thraustochytrids strains (Aurantiochytrium sp., Schizochytrium sp., Thraustochytrium sp., Ulkenia sp.) have been evaluated for production of biodiesel, long-chain omega-3 oils and exopolysaccharides (EPS), concluding that Aurantiochytrium sp. is the best candidate for production of biofuels, PUFAs and EPS [66]. Other algal 
strains like C. protothecoides, Galdieria sulphuraria, Nitzchia laevis, C. cohnii and Neochloris oleabundans [37], have been studied due to their content in hydrogen, lipids and carotenoids, presenting a great potential to be used at large scale. C. zofingiensis has been examined as a heterotrophic alternative to the microalga $H$. pluvialis for production of the carotenoid astaxanthin [73]. It should be mentioned that only a few bioactive compounds apart from lipids, such as astaxanthin and $\beta$-carotene, have been produced at industrial scale, due to the low production yields in microalgae cells and the difficulties in isolating/purifying them by economically feasible processes [74,75]. In order to further utilize microalgae advantages as means of bioconversion for more useful products, extensive research is being conducted on optimization of cultivation conditions and genetic engineering providing strains with high productivity yields of bioactive compounds.

\subsubsection{Downstream Processing}

Downstream processing involves several technologies that cover biomass harvesting, cell disruption and extraction and the final separation and purification step. In these processes are involved key factors that should be taken into account when an industrial scale up is being performed, such as low energy costs, scalability and specially a critical factor, all useful compounds like carbohydrates, pigments, $\omega-3$ fatty acids, proteins might maintain their functionality after downstream processing. Despite the efforts made during recent years, the downstream processing step is still one of the main responsible of the high cost of microalgae production at industrial scale [70]. In this context, heterotrophic cultivation system shows an interesting advantage due to its capacity to growth under all type of luminous conditions. Some studies have been demonstrated that the independence of light to growth is translated to higher biomass yield and consequently downstream processing steps are reduced. Under heterotrophic conditions, it is shown that $\omega-3$ fatty acid concentration can be two or three orders of magnitude greater that those under autotrophic conditions [76].

From an economical point of view, harvesting process is one of the major bottlenecks for commercialization of products from microalgae. Many efforts are being done to improve this step and it is one of the most challenging areas in the algal biofuel research. Current harvesting technologies applied include chemical, electrical, mechanical and biological based methods. In particular, cell flocculation technology to recover biomass from microalgae is becoming of great interest due to its capacity for treating large amounts of biomass with low energy cost [76,77]. In this context, bio-flocculation and auto-flocculation as novel flocculation based methods are highlighted among others, as it could be shown recently. Nevertheless, there are still some technical barriers to decrease costs and complexity of downstream processing in microalgae production that might be solved aiming future industrial applications [78,79].

On the other hand, as previously mentioned, extraction and purification steps might maintain the functionality of compounds of interest. It is critical in the case of carotenoids and lipids due to their facility for oxidizing in presence of light and oxygen. Using heterotrophic microalgae cultivation for biodiesel production, lipid content is the key factor and therefore special attention is being taken to reduce costs in this step. Traditionally organic solvent extraction was the most common method used with a lipid yield around 15-20\% depending on the solvent. Additional technologies were applied in combination with organic solvent extraction to improve lipid yield extraction such as microwave, sonication and homogenization. However, these methods result in higher energy consumption without the possibility of microalgae re-cultivation after solvent extraction due to the toxicity of solvents used. The potential of the fatty acids being used as a food additive usually prohibits the use of toxic solvents. Therefore, less-toxic, but unfortunately less effective, solvents, such as isopropanol, butanol, methyl tert-butyl ether (MTBE), acetic acid esters, hexane, 2-ethoxyethanol (2-EE) or ethanol have been also tested for microalgal lipid extraction [80]. Recently novel technologies are being studied, such as nanotechnology application, not only in the extraction but also in final transesterification step. A comprehensive description of the technology and different nanomaterials applied is reviewed by Zhang et al. (2013) [81], proving that nanomaterials are capable of efficiently extracting compounds 
from the cells, without any impact on microalgae growth. The studies of nanotechnology application in biodiesel production are still in lab-scale but preliminary results render this field promising and further research should be made in this direction.

\section{Discussion and Future Perspectives}

It appears that microalgae are a very promising type of biorefinery. Their advantage lies, not only on their ability to produce various high-added value metabolites, but also on the versatility that characterizes their growth modes. Microalgae can grow heterotrophically, as well as autotrophically, and even utilize carbon sources such as VFA. VFA are environmentally harmful by-products of dark fermentation process for the production of hydrogen from organic waste. Their utilization by heterotrophic microalgae for industrial production of lipids and carotenoids solves the economic problem that arises from the high cost of glucose as a carbon source. As it is proven, some microalgae genera such as Chlamydomonas, Chlorella, Crypthecodinium and Scenedesmus can grow well on VFA mixtures, even on dark fermentation effluents, with no significant inhibitory effects. In order to broaden our knowledge on the subject and establish an industrial method of utilizing VFA for microalgal metabolites production, attempts on further research are highly encouraged.

Acknowledgments: Angelina Chalima, Laura Oliver, Laura Fernández de Castro, Thomas Dietrich and Evangelos Topakas would like to thank VOLATILE, a project funded by the European Union's Horizon 2020 research and innovation program, under the grant agreement no. 720777. Anthi Karnaouri wishes to acknowledge financial support by the Greek State Scholarships (Postdoc-Research Scholarships IKY). Angelina Chalima would like to thank the Hellenic Foundation of Research and Innovation (ELIDEK) for financial support (ELIDEK Scholarships for Ph.D. Students).

Author Contributions: Evangelos Topakas and Thomas Dietrich conceived the content and structure of manuscript; Angelina Chalima, Laura Oliver, Laura Fernández de Castro and Anthi Karnaouri analyzed the literature data and wrote the paper.

Conflicts of Interest: The authors declare no conflict of interest.

\section{References}

1. Lee, W.S.; Chua, A.S.M.; Yeoh, H.K.; Ngoh, G.C. A review of the production and applications of waste-derived volatile fatty acids. Chem. Eng. J. 2014, 235, 83-99. [CrossRef]

2. Chen, Y.; Jiang, X.; Xiao, K.; Shen, N.; Zeng, R.J.; Zhou, Y. Enhanced volatile fatty acids (VFAs) production in a thermophilic fermenter with stepwise $\mathrm{pH}$ increase-Investigation on dissolved organic matter transformation and microbial community shift. Water Res. 2017, 112, 261-268. [CrossRef] [PubMed]

3. Perez-Garcia, O.; Escalante, F.M.E.; de-Bashan, L.E.; Bashan, Y. Heterotrophic cultures of microalgae: Metabolism and potential products. Water Res. 2011, 45, 11-36. [CrossRef] [PubMed]

4. Venkata Mohan, S.; Prathima Devi, M. Fatty acid rich effluent from acidogenic biohydrogen reactor as substrate for lipid accumulation in heterotrophic microalgae with simultaneous treatment. Bioresour. Technol. 2012, 123, 627-635. [CrossRef] [PubMed]

5. Sinha, B. Omega-3 Market by Type (ALA, EPA, and DHA), Source (Fish Oil \& Krill Oil, Algal Oil, Walnut, Pumpkin Seeds, Soybean Oil, Canola Oil, Bean Curd, and Others), Application (Dietary Supplement, Pharmaceutical, Infant Formula, Food \& Beverage, Pet Food, and Fish Feed)-Global Opportunity Analysis and Industry Forecast, 2014-2022. Allied Market Research: Portland, OR, USA, 2016. Available online: https:/ / www.alliedmarketresearch.com/omega-3-market (accessed on 29 August 2016).

6. Sprague, M.; Dick, J.R.; Tocher, D.R. Impact of sustainable feeds on omega-3 long-chain fatty acid levels in farmed Atlantic salmon, 2006-2015. Sci. Rep. 2016, 6, 21892. [CrossRef] [PubMed]

7. Huang, Y.L.; Wu, Z.; Zhang, L.; Cheung, C.M.; Yang, S.T. Production of carboxylic acids from hydrolyzed corn meal by immobilized cell fermentation in a fibrous-bed bioreactor. Bioresour. Technol. 2002, 82, 51-59. [CrossRef]

8. Arudchelvam, Y.; Perinpanayagam, M.; Nirmalakhandan, N. Predicting VFA formation by dark fermentation of particulate substrates. Bioresour. Technol. 2010, 101, 7492-7499. [CrossRef] [PubMed] 
9. Singhania, R.R.; Patel, A.K.; Christophe, G.; Fontanille, P.; Larroche, C. Biological upgrading of volatile fatty acids, key intermediates for the valorization of biowaste through dark anaerobic fermentation. Bioresour. Technol. 2013, 145, 166-174. [CrossRef] [PubMed]

10. Hu, B.; Zhou, W.; Min, M.; Du, Z.; Chen, P.; Ma, X.; Liu, Y.; Lei, H.; Shi, J.; Ruan, R. Development of an effective acidogenically digested swine manure-based algal system for improved wastewater treatment and biofuel and feed production. Appl. Energy 2013, 107, 255-263. [CrossRef]

11. Yan, Y.; Feng, L.; Zhang, C.; Wisniewski, C.; Zhou, Q. Ultrasonic enhancement of waste activated sludge hydrolysis and volatile fatty acids accumulation at pH 10.0. Water Res. 2010, 44, 3329-3336. [CrossRef] [PubMed]

12. Pham, T.N.; Nam, W.J.; Jeon, Y.J.; Yoon, H.H. Volatile fatty acids production from marine macroalgae by anaerobic fermentation. Bioresour. Technol. 2012, 124, 500-503. [CrossRef] [PubMed]

13. Fu, Z.; Holtzapple, M.T. Consolidated bioprocessing of sugarcane bagasse and chicken manure to ammonium carboxylates by a mixed culture of marine microorganisms. Bioresour. Technol. 2010, 101, 2825-2836. [CrossRef] [PubMed]

14. Han, W.; Chen, H.; Jiao, A.; Wang, Z.; Li, Y.; Ren, N. Biological fermentative hydrogen and ethanol production using continuous stirred tank reactor. Int. J. Hydrogen Energy 2012, 37, 843-847. [CrossRef]

15. Ding, H.B.; Tan, G.Y.A.; Wang, J.Y. Caproate formation in mixed-culture fermentative hydrogen production. Bioresour. Technol. 2010, 101, 9550-9559. [CrossRef] [PubMed]

16. Teghammar, A.; Yngvesson, J.; Lundin, M.; Taherzadeh, M.J.; Horváth, I.S. Pretreatment of paper tube residuals for improved biogas production. Bioresour. Technol. 2010, 101, 1206-1212. [CrossRef] [PubMed]

17. Wikandari, R.; Gudipudi, S.; Pandiyan, I.; Millati, R.; Taherzadeh, M.J. Inhibitory effects of fruit flavors on methane production during anaerobic digestion. Bioresour. Technol. 2013, 145, 188-192. [CrossRef] [PubMed]

18. Zhou, A.; Du, J.; Varrone, C.; Wang, Y.; Wang, A.; Liu, W. VFAs bioproduction from waste activated sludge by coupling pretreatments with Agaricus bisporus substrates conditioning. Process Biochem. 2014, 49, $283-289$. [CrossRef]

19. Xu, G.; Chen, S.; Shi, J.; Wang, S.; Zhu, G. Combination treatment of ultrasound and ozone for improving solubilization and anaerobic biodegradability of waste activated sludge. J. Hazard. Mater. 2010, 180, 340-346. [CrossRef] [PubMed]

20. Zhou, A.; Yang, C.; Guo, Z.; Hou, Y.; Liu, W.; Wang, A. Volatile fatty acids accumulation and rhamnolipid generation in situ from waste activated sludge fermentation stimulated by external rhamnolipid addition. Biochem. Eng. J. 2013, 77, 240-245. [CrossRef]

21. Kim, H.J.; Choi, Y.G.; Kim, G.D.; Kim, S.H.; Chung, T.H. Effect of enzymatic pretreatment on solubilization and volatile fatty acid production in fermentation of food waste. Water Sci. Technol. 2005, 52, 51-59. [CrossRef] [PubMed]

22. Kim, H.J.; Kim, S.H.; Choi, Y.G.; Kim, G.D.; Chung, T.H. Effect of enzymatic pretreatment on acid fermentation of food waste. J. Chem. Technol. Biotechnol. 2006, 81, 947-980. [CrossRef]

23. Bayr, S.; Kaparaju, P.; Rintala, J. Screening pretreatment methods to enhance thermophilic anaerobic digestion of pulp and paper mill wastewater treatment secondary sludge. Chem. Eng. J. 2013, 223, 479-486. [CrossRef]

24. Yang, Q.; Luo, K.; Li, M.X.; Bo Wang, D.; Zheng, W.; Zeng, M.G.; Liu, J.J. Enhanced efficiency of biological excess sludge hydrolysis under anaerobic digestion by additional enzymes. Bioresour. Technol. 2010, 101, 2924-2930. [CrossRef] [PubMed]

25. Golub, K.W.; Smith, A.D.; Hollister, E.B.; Gentry, T.J.; Holtzapple, M.T. Investigation of intermittent air exposure on four-stage and one-stage anaerobic semi-continuous mixed-acid fermentations. Bioresour. Technol. 2011, 102, 5066-5075. [CrossRef] [PubMed]

26. Borzacconi, L.; Lopez, I.; Anido, C. Hydrolysis constant and VFA inhibition in acidogenic phase of MSW anaerobic degradation. Water Sci. Technol. 1997, 36, 479-484. [CrossRef]

27. Zhou, A.; Guo, Z.; Yang, C.; Kong, F.; Liu, W.; Wang, A. Volatile fatty acids productivity by anaerobic co-digesting waste activated sludge and corn straw: Effect of feedstock proportion. J. Biotechnol. 2013, 168, 234-239. [CrossRef] [PubMed]

28. Feng, L.; Chen, Y.; Zheng, X. Enhancement of waste activated sludge protein conversion and volatile fatty acids accumulation during waste activated sludge anaerobic fermentation by carbohydrate substrate addition: The effect of pH. Environ. Sci. Technol. 2009, 43, 4373-4380. [CrossRef] [PubMed] 
29. Yu, H.Q.; Fang, H.H.P. Acidification of mid- and high-strength dairy wastewaters. Water Res. 2001, 35, 3697-3705. [CrossRef]

30. Pessiot, J.; Nouaille, R.; Jobard, M.; Singhania, R.R.; Bournilhas, A.; Christophe, G.; Fontanille, P.; Peyret, P.; Fonty, G.; Larroche, C. Fed-batch anaerobic valorization of slaughterhouse by-products with mesophilic microbial consortia without methane production. Appl. Biochem. Biotechnol. 2012, 167, 1728-1743. [CrossRef] [PubMed]

31. Turon, V.; Trably, E.; Fayet, A.; Fouilland, E.; Steyer, H.Q. Raw dark fermentation effluent to support heterotrophic microalgae growth: Microalgae successfully outcompete bacteria for acetate. Algal Res. 2015, 12, 119-125. [CrossRef]

32. Yu, H.Q.; Fang, H.H.P. Acidogenesis of gelatin-rich wastewater in an upflow anaerobic reactor: Influence of pH and temperature. Water Res. 2003, 37, 55-66. [CrossRef]

33. Ji, Z.; Chen, G.; Chen, Y. Effects of waste activated sludge and surfactant addition on primary sludge hydrolysis and short-chain fatty acids accumulation. Bioresour. Technol. 2010, 101, 3457-3462. [CrossRef] [PubMed]

34. Chang, H.N.; Kim, N.J.; Kang, J.; Jeong, C.M. Biomass-derived volatile fatty acid platform for fuels and chemicals. Biotechnol. Bioprocess Eng. 2010, 15, 1-10. [CrossRef]

35. Bengtsson, S.; Hallquist, J.; Werker, A.; Welander, T. Acidogenic fermentation of industrial wastewaters: Effects of chemostat retention time and $\mathrm{pH}$ on volatile fatty acids production. Biochem. Eng. J. 2008, 40, 492-499. [CrossRef]

36. Huang, L.; Chen, B.; Pistolozzi, M.; Wu, Z.; Wang, J. Inoculation and alkali coeffect in volatile fatty acids production and microbial community shift in the anaerobic fermentation of waste activated sludge. Bioresour. Technol. 2014, 153, 87-94. [CrossRef] [PubMed]

37. Jie, W.; Peng, Y.; Ren, N.; Li, B. Volatile fatty acids (VFAs) accumulation and microbial community structure of excess sludge (ES) at different pHs. Bioresour. Technol. 2014, 152, 124-129. [CrossRef] [PubMed]

38. Liu, C.H.; Chang, C.Y.; Liao, Q.; Zhu, X.; Chang, J.S. Photoheterotrophic growth of Chlorella vulgaris ESP6 on organic acids from dark hydrogen fermentation effluents. Bioresour. Technol. 2013, 145, 331-336. [CrossRef] [PubMed]

39. Morales-Sánchez, D.; Martinez-Rodriguez, O.A.; Kyndt, J.; Martinez, A. Heterotrophic growth of microalgae: Metabolic aspects. World J. Microbiol. Biotechnol. 2015, 31, 1-9. [CrossRef] [PubMed]

40. Barclay, W.R.; Meager, K.M.; Abril, J.R. Heterotrophic production of long chain omega - 3 fatty acids utilizing algae and algae - like microorganisms. J. Appl. Phycol. 1994, 6, 123-129. [CrossRef]

41. Pérez-Garcia, O.; Bashan, Y. Microalgal heterothophic and mixotrophic culturing for bio-refining: From metabolic routes to techno-economics. In Algal Biorefineries; Prokop, A., Bajpai, R.K., Zappi, M.E., Eds.; Springer International Publishing: Cham, Switzerland, 2015; pp. 61-131. [CrossRef]

42. Turon, V.; Baroukh, C.; Trably, E.; Latrille, E.; Fouilland, E.; Steyer, J.P. Use of fermentative metabolites for heterotrophic microalgae growth: Yields and kinetics. Bioresour. Technol. 2015, 175, 342-349. [CrossRef] [PubMed]

43. Turon, V.; Trably, E.; Fouilland, E.; Steyer, J.P. Potentialities of dark fermentation effluents as substrates for microalgae growth: A review. Process Biochem. 2016, 51, 1843-1854. [CrossRef]

44. Miller, R.; Wu, G.; Deshpande, R.R.; Vieler, A.; Gärtner, K.; Li, X.; Moellering, E.R.; Zäuner, S.; Cornish, A.J.; Liu, B.; et al. Changes in transcript abundance in Chlamydomonas reinhardtii following nitrogen deprivation predict diversion of metabolism. Plant Physiol. 2010, 154, 1737-1752. [CrossRef] [PubMed]

45. Wase, N.; Black, P.N.; Stanley, B.A.; DiRusso, C.C. Integrated quantitative analysis of nitrogen stress response in Chlamydomonas reinhardtii using metabolite and protein profiling. J. Proteome Res. 2014, 13, 1373-1396. [CrossRef] [PubMed]

46. Kunze, M.; Pracharoenwatana, I.; Smith, S.M.; Hartig, A. A central role for the peroxisomal membrane in glyoxylate cycle function. Biochim. Biophys. Acta 2006, 1763, 1441-1452. [CrossRef] [PubMed]

47. Kang, C.D.; Lee, J.S.; Park, T.H.; Sim, S.J. Comparison of heterotrophic and phtoautotrophic induction on astaxanthin production by Haematococcus pluvialis. Appl. Microbiol. Biotechnol. 2005, 68, 237-241. [CrossRef] [PubMed]

48. Moon, M.; Kim, C.W.; Park, W.K.; Yoo, G.; Choi, Y.E.; Yang, J.W. Mixotrophic growth with acetate or volatile fatty acids maximizes growth and lipid production in Chlamydomonas reinhardtii. Algal Res. 2013, 2, 352-357. [CrossRef] 
49. Heredia-Arroyo, T.; Wei, W.; Hu, B. Oil accumulation via heterotrophic/mixotrophic Chlorella protothecoides. Appl. Biochem. Biotechnol. 2010, 162, 1978-1995. [CrossRef] [PubMed]

50. Wen, Q.; Chen, Z.; Li, P.; Duan, R.; Ren, N. Lipid production for biofuels from hydrolyzate of waste activated sludge by heterotrophic Chlorella protothecoides. Bioresour. Technol. 2013, 143, 695-698. [CrossRef] [PubMed]

51. Fei, Q.; Fu, R.; Shang, L.; Brigham, C.J.; Chang, H.N. Lipid production by microalgae Chlorella protothecoides with volatile fatty acids (VFAs) as carbon sources in heterotrophic cultivation and its economic assessment. Bioprocess Biosyst. Eng. 2015, 38, 691-700. [CrossRef] [PubMed]

52. Turon, V.; Trably, E.; Fouilland, E.; Steyer, J.P. Growth of Chlorella sorokiniana on a mixture of volatile fatty acids: The effects of light and temperature. Bioresour. Technol. 2015, 198, 852-860. [CrossRef] [PubMed]

53. Ryu, B.G.; Kim, W.; Heo, S.W.; Kim, D.; Choi, G.G.; Yang, J.W. Advanced treatment of residual nitrogen from biologically treated coke effluent by a microalga-mediated process using volatile fatty acids (VFAs) under stepwise mixotrophic conditions. Bioresour. Technol. 2015, 191, 488-495. [CrossRef] [PubMed]

54. Syrett, P.J.; Bocks, S.M.; Merrett, M.J. The Assimilation of Acetate by Chlorella vulgaris. J. Exp. Bot. 1969, 15, 35-47. [CrossRef]

55. Ratledge, C.; Kanagachandran, K.; Anderson, A.J.; Grantham, D.J.; Stephenson, J.C. Production of docosahexaenoic acid by Crypthecodinium cohnii grown in a $\mathrm{pH}$-auxostat culture with acetic acid as principal carbon source. Lipids 2001, 36, 1241-1246. [CrossRef]

56. Combres, C.; Laliberte, G.; Reyssac, J.S.; de la Noue, J. Effect of acetate on growth and ammonium uptake in the microalga Scenedesmus obliquus. Physiol. Plant 1994, 91, 729-734. [CrossRef]

57. Ren, H.Y.; Liu, B.-F.; Ma, C.; Zhao, L.; Ren, N.Q. A new lipid-rich microalga Scenedesmus sp. strain R-16 isolated using Nile red staining: Effects of carbon and nitrogen sources and initial $\mathrm{pH}$ on the biomass and lipid production. Biotechnol. Biofuels 2013, 6, 143. [CrossRef] [PubMed]

58. Matsuka, M.; Miyachi, S.; Hase, E. Acetate metabolism in the process of 'acetate-bleaching' of Chlorella protothecoides. Plant Cell Physiol. 1969, 538, 527-538. [CrossRef]

59. Egli, T.; Lendenmann, U.; Snozzi, M. Kinetics of microbial growth with mixtures of carbon sources. Antonie Van Leeuwenhoek 1993, 63, 289-298. [CrossRef]

60. Cho, H.U.; Kim, Y.M.; Choi, Y.N.; Xu, X.; Shin, D.Y.; Park, J.M. Effects of pH control and concentration on microbial oil production from Chlorella vulgaris cultivated in the effluent of a low-cost organic waste fermentation system producing volatile fatty acids. Bioresour. Technol. 2015, 184, 245-250. [CrossRef] [PubMed]

61. Chen, G.Q.; Chen, F. Growing phototrophic cells without light. Biotechnol. Lett. 2006, 28, 607-616. [CrossRef] [PubMed]

62. Lin, X.; Xiong, L.; Qi, G.; Shi, S.; Huang, C.; Chen, X.; Chen, X. Using butanol fermentation wastewater for biobutanol production after removal of inhibitory compounds by micro/mesoporous hyper-cross-linked polymeric adsorbent. ACS Sustain. Chem. Eng. 2015, 3, 702-709. [CrossRef]

63. Caporgno, M.P.; Taleb, A.; Olkiewicz, M.; Font, J.; Pruvost, J.; Legrand, J.; Bengoa, C. Microalgae cultivation in urban wastewater: Nutrient removal and biomass production for biodiesel and methane. Algal Res. 2015, 10, 232-239. [CrossRef]

64. Khan, R.S.; Grigor, J.; Winger, R.; Win, A. Functional food product development-Opportunities and challenges for food manufacturers. Trends Food Sci. Technol. 2013, 30, 27-37. [CrossRef]

65. Alabdukarim, B.; Bakeet, Z.A.N.; Arzoo, S. Role of some functional lipids in preventing diseases and promoting health. J. K. Saud Univ. Sci. 2012, 24, 319-329. [CrossRef]

66. Hooper, L.; Thompson, R.L.; Harrison, R.A.; Summerbell, C.D.; Ness, A.R.; Moore, H.J.; Worthington, H.V.; Durrington, P.N.; Higgins, J.P.T.; Nigel, E.C.; et al. Risks and benefits of omega 3 fats for mortality, cardiovascular disease, and cancer: Systematic review. Br. Med. J. 2006, 332, 752-755. [CrossRef] [PubMed]

67. Tacon, A.G.J.; Metian, M. Global overview on the use of fish meal and fish oil in industrially compounded aquafeeds: Trends and future prospects. Aquaculture 2008, 285, 146-158. [CrossRef]

68. Stonik, V.A.; Fedorov, S.N. Marine low molecular weight natural products as potential cancer preventive compounds. Mar. Drugs 2014, 12, 636-671. [CrossRef] [PubMed]

69. Xu, H.; Miao, X.; Wu, Q. High quality biodiesel production from a microalga Chlorella protothecoides by heterotrophic growth in fermenters. J. Biotechnol. 2006, 126, 499-507. [CrossRef] [PubMed] 
70. Hu, Q.; Sommerfeld, M.; Jarvis, E.; Ghirardi, M.; Posewitz, M.; Seibert, M.; Darzins, A. Microalgal triacylglycerols as feedstocks for biofuel production: Perspectives and advances. Plant J. 2008, 54, 621-639. [CrossRef] [PubMed]

71. Allen, J.W.; DiRusso, C.C.; Black, P.N. Triacylglycerol synthesis during nitrogen stress involves the prokaryotic lipid synthesis pathway and acyl chain remodeling in the microalgae Coccomyxa subellipsoidea. Algal Res. 2015, 10, 110-120. [CrossRef]

72. Wase, N.; Tu, P.; Allen, J.W.; Black, P.N.; DiRusso, C.C. Identification and metabolite profiling of chemical activators of lipid accumulation in green algae. Plant Physiol. 2017. [CrossRef] [PubMed]

73. Liu, J.; Sun, Z.; Gerken, H.; Liu, Z.; Jiang, Y.; Chen, F. Chlorella zofingiensis as an alternative microalgal producer of astaxanthin: Biology and industrial potential. Mar Drugs. 2014, 12, 3487-3515. [CrossRef] [PubMed]

74. Clarens, A.; Resurreccion, E.; White, M.; Colosi, L. Environmental life cycle comparison of algae to other bioenergy feedstocks. Environ. Sci. Technol. 2010, 44, 1813-1819. [CrossRef] [PubMed]

75. Norsker, N.; Barbosa, M.; Vermue, M.; Wijffels, R. Microalgal production-a close look at the economics. Biotechnol. Adv. 2011, 29, 24-27. [CrossRef] [PubMed]

76. Vandamme, D.; Foubert, I.; Muylaert, K. Flocculation as a low-cost method for harvesting microalgae for bulk biomass production. Trends Biotechnol. 2013, 31, 233-239. [CrossRef] [PubMed]

77. Salim, S.; Kosterink, N.R.; Wacka, N.T.; Vermue, M.H.; Wijffels, R.H. Mechanism behind autoflocculation of unicellular green microalgae Ettliatexensis. J. Biotechnol. 2014, 174, 34-38. [CrossRef] [PubMed]

78. Wan, C.; Alam, M.A.; Zhao, X.Q.; Zhang, X.Y.; Guo, S.L.; Ho, S.H.; Chang, J.S.; Bai, F.W. Current progress and future prospect of microalgal biomass harvest using various flocculation technologies. Bioresour. Technol. 2015, 184, 251-257. [CrossRef] [PubMed]

79. Ummalyma, S.B.; Gnansounou, E.; Sukumaran, R.K.; Sindhy, R.; Pandey, A.; Sahoo, D. Bioflocculation: An alternative strategy for harvesting of microalgae-An overview. Bioresour. Technol. 2017, 242, 227-235. [CrossRef] [PubMed]

80. Ranjith Kumar, R.; Hanumantha Rao, P.; Arumugam, M. Lipid extraction methods from microalgae: A comprehensive review. Front. Energy Res. 2015, 2, 1-9. [CrossRef]

81. Zhang, X.L.; Yan, S.; Tyagi, R.D.; Surampalli, R.Y. Biodiesel production from heterotrophic microalgae through transesterification and nanotechnology application in the production. Renew. Sustain. Energy Rev. 2013, 26, 216-223. [CrossRef] 